\title{
Third A.S. Geyser Commemorative Lecture on 30 March 2017: Welcoming address by the moderator of the executive of the General Assembly of the Netherdutch Reformed Church of Africa
}

\begin{tabular}{|c|c|}
\hline \multicolumn{2}{|c|}{$\begin{array}{l}\text { Author: } \\
\text { André G. Ungerer }{ }^{1,2}\end{array}$} \\
\hline \multicolumn{2}{|c|}{$\begin{array}{l}\text { Affiliations: } \\
{ }^{1} \text { Reformed Theological } \\
\text { College, Faculty of Theology, } \\
\text { University of Pretoria, } \\
\text { South Africa }\end{array}$} \\
\hline \multicolumn{2}{|c|}{$\begin{array}{l}{ }^{2} \text { Netherdutch Reformed } \\
\text { Church of Africa, South Africa }\end{array}$} \\
\hline \multicolumn{2}{|c|}{$\begin{array}{l}\text { Research Project Registration: } \\
\text { Project Leader: A. Ungerer } \\
\text { Project Number: } 82329542\end{array}$} \\
\hline \multicolumn{2}{|c|}{$\begin{array}{l}\text { Corresponding author: } \\
\text { André Ungerer, } \\
\text { andre.ungerer@up.ac.za }\end{array}$} \\
\hline \multicolumn{2}{|c|}{$\begin{array}{l}\text { How to cite this article: } \\
\text { Ungerer, A.G., 2017, 'Third } \\
\text { A.S. Geyser Commemorative } \\
\text { Lecture on } 30 \text { March 2017: } \\
\text { Welcoming address by the } \\
\text { moderator of the executive of } \\
\text { the General Assembly of } \\
\text { the Netherdutch Reformed } \\
\text { Church of Africa', HTS } \\
\text { Teologiese Studies/ } \\
\text { Theological Studies 73(1), } \\
\text { a4653. https://doi. } \\
\text { org/10.4102/hts.v73i1.4653 }\end{array}$} \\
\hline \multicolumn{2}{|c|}{$\begin{array}{l}\text { Copyright: } \\
\text { (C) 2017. The Authors. } \\
\text { Licensee: AOSIS. This work } \\
\text { is licensed under the } \\
\text { Creative Commons } \\
\text { Attribution License. }\end{array}$} \\
\hline \multicolumn{2}{|l|}{ Read online: } \\
\hline 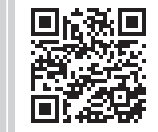 & $\begin{array}{l}\text { Scan this QR } \\
\text { code with your } \\
\text { smart phone or } \\
\text { mobile device } \\
\text { to read online. }\end{array}$ \\
\hline
\end{tabular}

With the wisdom of hindsight, I briefly want to reflect on some events in the past. Of course, there are many good things to say about the past, but given that the lecture of Dr Wim Dreyer is about Albert Geyser, it is also necessary to reflect on some regrettable actions of the Hervormde Kerk [Netherdutch Reformed Church] in this regard. The Hervormde Kerk is the Church I have known from childhood and the Church I love dearly in spite of her shortcomings.

I want to reflect on this with great humility both as a member and as the current moderator of the Hervormde Kerk. Humility is called for because, as a young pastor in the Church at the end of the eighties, I kept silent in spite of my uneasiness with Article III - the controversial article in the Netherdutch Reformed Church's Constitution that regulated exclusivist racial membership of the Church and denounced interracial marriage. Fortunately, Article III died a natural death and was eventually removed from the Constitution at the end of the nineties. Another remnant of Article III, namely the Volkskerk (nation church) ideology (Ordereël IV in the Constitution), was voted out at the 71st General Assembly of October 2016 - the assembly I was honoured to lead as newly elected moderator.

With a few brushstrokes, I want to reflect particularly on the courageous acts of three men during the apartheid era. The first, of course, was Albert Geyser, and the other two were Professor Adrianus van Selms and Professor Cas Labuschagne - both of them in support of Geyser and against Article III and the Hervormde Kerk's endorsement of the policy of apartheid.

In a nutshell, over a period of time, the Hervormde Kerk removed all three of these men in a dishonourable way. The Church, saturated with the ideology of separateness (the rhetoric: 'three great dangers of Catholicism, Communism and blackness'; [drie groot gevare ... die Roomse gevaar, die rooi gevaar en die swart gevaar]) and nationalism, used every possible means to sustain the system of apartheid and discredit its opponents.

In 1962, Geyser was found guilty of heresy by the Executive of the General Assembly and he resigned as a professor at the University of Pretoria. Dr Cas Labuschagne, a supporter of Geyser and lecturer in Biblical studies, was replaced by Dr J.I. de Wet. Labuschagne heard of this on the radio. He was never officially notified. In 1963, the Church decided that Van Selms' resignation as lecturer automatically meant that he was no longer a minister of the Netherdutch Reformed Church.

Geyser turned to the Supreme Court to appeal the Church's guilty verdict on the heresy charge. Geyser won the appeal case and the Church was obligated to reinstate him as a minister of the Church. A second trial followed in 1967. Geyser brought a charge of defamation against Professor Adriaan Pont. The Church aided Pont financially, and even after the guilty verdict by the Supreme Court, no action was taken by the Church against Pont.

Subsequently, Van Selms and Labuschagne resigned as members of the Church on 18 June 1967. Both became members of the St Andrews Presbyterian Church in Pretoria. Later that year, Geyser also announced his resignation from the Netherdutch Reformed Church.

This, dear friends, was a bird's-eye view on the fate of Geyser and two of his supporters. The reason? Geyser himself expressed it best: Should the Church no longer confess Christ then it has lost 
its heart. This vacuum will then be filled by an ideology - that of political power and nationalism. It was this ideology that led to the regrettable actions in the past of the Hervormde Kerk. With the wisdom of hindsight, I would wish that it could be erased, but that is not possible. It is a past that can haunt us to the end of time, or it can be a past (as sad as it was) that we can learn from - never to make the same mistakes again. 